\title{
WAT IMPLISEER DIE STRYD TEEN SIEKTES?
}

Die stryd teen siektes is nie 'n probleem slegs van ons huidige tyd nie maar dateer reeds sedert die dae van die Bybelse geskiedenis. Die enigste verskil is dat die wapens steeds meer modern word en die stryd in omvang toeneem. Dat dit so moet wees spreek vanself want die welvaart van 'n land is in ' $n$ baie groot mate van die fisiese welsyn van sy burgers afhanklik. Geen wonder dus dat volksgesondheid so 'n belangrike plek in die huishouding van elke verantwoordelike regering inneem nie. Dit is egter veel meer as 'n nasionale probleem, dit is een wat op internasionale vlak ernstige aandag en samewerking geniet. In hierdie verband kan gedink word aan die Wêreld-Gesondheidsorganisasie wat hom die verhoging van die gesondheidspeil van die wêreldbevolking ten doel stel.

Dit is nodig dat onderskei sal word tussen voorkombare siektes, waarvan aansteeklike siektes die belangrikste groep uitmaak, en nie-voorkombare siektes. Voorkomende openbare gesondheidsdienste is daargestel vir die bestryding van eersgenoemde groep. SuidAfrika het reeds ver op hierdie weg gevorder maar nie voordat groot offers gebring is om die Staat van sy verantwoordelikheid in dié verband bewus te maak nie. Die openbare gesondheidsbeweging en die Departement van Volksgesondheid in SuidAfrika is gebore uit die spore van dood wat deur die kwaadaardige griepepidemie van 1918 nagelaat is en is beliggaam in die Publieke Gesondheidswet van 1919 .
Hierdie stryd word nie net deur die medici gevoer nie. Inteendeel, die heersende toestande is sodanig dat die mediese praktisyn sy hande so vol het met die verskaffing van geneeskundige dienste dat hy weinig aandag aan die voorkoming van siektes kan bestee. Dit is daarom ook die taak van persone buite die mediese professie waarin elkeen wat daarby betrokke is, van diegene wat vir nagvuilverwydering verantwoordelik is tot die beroemdste navorser, 'n ewe belangrike bydrae lewer. Baie mense is egter nog totaal onbewus van en ondankbaar vir die belangrike werk wat in stilte verrig word deur diegene wie se primêre taak dit is om toestande wat 'n bedreiging vir die gesondheid van sy medemens inhou te verwyder en te voorkom. Nog bejammerenswaardiger is die omstandigheid dat hierilie persone, bv. munisipale gesondheidsbeamptes, wat in die uitvoering van noodsaaklike pligte 'n groot diens aan hul gemeenskap bewys, so maklik in enguns raak en dikwels die mees gehate persone is.

Die voorkoming en bestryding van aansteeklike siektes het baie fasette wat tweërlei doel dien. In die eerste plek is die strewe om die moontlike ontstaan van siektes te voorkom en tweedens om 'n siekte wat uitgebreek het so gou moontlik onder beheer te bring en verspreiding daarvan te bekamp. Dic belangrikstes van hierdie maatreëls kan hier slegs kortliks behandel word.

Deur navorsing is die aktief kunsmatige immunisasie van dic mens teen 'n groot aantal aansteeklike siektes 
moontlik gemaak. Hoewel hierdie metodes geensins onfeilbaar is nic sal die waarde daarvan en die noodsaaklikheid om daarvan gebruik te maak seker deur elkeen geredelik tocgegee word, veral vir siektes soos pokke, witseerkeel en polio wat maklik epidemiese afmetings kan aanneem.

Waar aktiewe immunisasie vanweë die lang tyd wat daarvoor nodig is in tye van epidemieë of van persone wat met ernstige siektes in aanraking was, onprakties is, moet van passiewe immunisasie gebruik gemaak word. Dit behels die toediening van immune serum d.w.s. die serum van diere wat teen die betrokke siektes geïmmuniseer is en wat die spesifieke teenliggame bevat. Dit verleen onmiddellike beskerming wat egter van korte duur is en slegs dien om persone gedurende die gevaarperiode te beskerm. Hierdie dienste word gewoonlik deur munisipale gesondheidsdepartemente verskaf of by hul klinieke of by wyse van massainentingsveldtogte. Waar daar gecn plaaslike gesondheidsdepartement is nie word dit deur die distriksgeneesheer gedoen.

Omdat voedisel een van die belangrikste maniere is waarop siektes versprei word moet die verantwoordelike instansies besondere aandag hieraan skenk veral t.o.v. inspeksie by die produksie, bereiding en verspreiding.

Vleis is dikwels die draer van siekte deurdat dit van siek diere afkomstig is of omdat dit sekondêr besmet word deur onsindelike slagprosesse en hantering, ondoeltreffende slagplekke en deurdat persone wat daarmee werk aan besmet- like siektes mag ly of draers daarvan is. Volledige regulasies aangaande elke aspek in die verband is deur wetgewing neergelê. Siektes wat deur vleis versprei kan word sluit o.a. in tuberkulose, lintwurmbesmetting, miltsiekte, aktinomikose, bek- en klouseer, varkkoors ens.

Hoewel melk een van die voedsaam. ste voedselprodukte is, kan dit ook dic gevaarlikste wees vanweë die gunstige medium wat ait vir die groei en vermenigvuldiging van bakterieë bied en siektes soos tuberkulose, maagkoors, disenterie, witseerkeel, skarlakenkoors en MIaltakoors word dikwels daardeur versprei. Slegs in enkele gevalle, bv. tuberkulose en Maltakoors, is die bakterieë van siek koeie afkomstig. Origens word die melk sekondêr besmet uit bronne wat sonder uitsondering na die mens teruggevoer kan word.

Ander voedselsoorte, bv. ingemaakte of andersins gepreserveerde voedsels, kan in 'n mindere mate die draers van siektes soos bakteriese voedselvergiftiging wees.

Die openbare watervoorsiening in die meeste dorpe en stede is afkomstig uit riviere wat noodwendig produkte van menslike en dierlike oorsprong sal bevat. Dit is dus vanselfsprekend dat dit 'n draer van bakteriese en veral ingewandsiektes sal wees. Hierbenewens skep dit ook die gevaar van besmetting met siekteverwekkende parasitiese organismes soos dié wat bilharziase en amebiese disenterie veroorsaak in dié gebiede waar die siektes endemies is. Die gevare verbonde aan die gebruik van ongesuiwerde water kan gevolglik deur niemand betwis word nie. 
Die gereelde en doeltreffende verwydering en onskadelikmaking van menslike ekskreta is een van die noodsaaklikste gesondheidsdienste aangesien dit die bakterieë van gevaardlike ingewandsiektes, die virus van polio sowel as ander skadelike parasiete of hul eiers kan huisves. Dit dien as ' $n$ belangrike bron waarvandaan voedsel en water besmet kan word.

'n Groot aantal siektes van die mens word deur parasiete veroorsaak of word deur parasitiese organismes na die mens oorgedra. Om hierdie siektes die hoof te bied en uit te wis moet hierdic organismes bestry en vernietig word. Aandag moet o.a. geskenk word aan die bilharzia-parasiet en sy slaktussengasheer, rotte en ander knaagdiere as draers van pes en die vlooi wat dit na die mens oordra, luise as die draers van tifuskoors en muskiete as draers van geelkoors en malaria.

Daar moet voortdurend gewaak word teen die toevallige invoering van kwaadaardige aansteeklike siektes van buite die grense van die Unie. Indien geelkoorsgevalle bv. die land sou binnekom kan die siekte maklik hier 'n vastrapplek kry aangesien die muskiet wat dit oordra. Aëdes aegypti, in Natal voorkoin.

Vroegtydige aanmelding van ernstige siektes is ' $n$ voorvereiste vir onmiddeIlike optrede daarteen en word deur die wet verpligtend gemaak. Hiervoor word veral ouers en voogde, hoofde van huishoudings, skoolhoofde, Bantoehoofmanne ens. verantwoordelik gehou. Geen optrede teen verspreiding van 'n siekte kan doeltreffend wees as die oorspong van besmetting nie so gou moontlik opgespoor en uit die weg geruim word nie.

In omvang is die stryd nie slegs tot hierdie maatreëls beperk nie maar moet dit ook op ander terreine soos ontsmetting, behuising en ventilasie, voorkoming van lugbesoedeling en industriële higiëne gevoer word. Hier geld dit egter nie slegs aansteeklike siektes nie maar ook ander voorkombare siektes. Behalwe bakteriese vergiftiging deur voedsel moet daar gewaak word teen vergiftiging met ander stowwe wat in voedsel, water en lug kan voorkom.

Vir die persoon wat hom op die terrein van openbare gesondheid begeef is dit nodig om 'n grondige kennis van elkeen van die verskillende aspekte te besit, wat veel dieper gaan as wat uit 'n kort oorsig soos bogenoemde mag blyk. Wanneer besondere aandag aan die voorkoming van aansteeklike siektes geskenk word sal besef word dat elkeen van dié maatreëls tot een enkele kern nl. 'n basiese kennis van mikrobiologie, teruggevoer moet word. Die leek is heeltemal tevrede om te verneem dat ' $n$ besondere siekte deur ' $n$,kiem" veroorsaak word en dat hy moontlik deur antibiotiese middels daarvan genees sal kan word. Die persoon wat daarmee gemoeid is moet egter weet of die toestand deur 'n bakterie, rickettsia, virus, swam of protosoön veroorsaak word en deur watter spesifieke een. Die organisme se eienskappe moet bekend wees. Alle mikro-organismes word nie altyd ewe doeltreffend deur 'n ontsmettingsmiddel gedood nie en almal kan nie ewe effektief deur antibiotika bestry word 
nie. Dié wat wel sensitief vir 'n besondere antibiotiese middel is mag 'n weerstand daarteen ontwikkel sodat dit geen uitwerking meer het nie.

Die versameling van al hierdie kennis is alleen deur volgehoue navorsing moontlik gemaak, nie alleen ten einde middels en maatreëls te vind teen nog onoorwonne siektes nie maar ook om die reeds bestaande te verbeter en dit doeltreffender te maak. Hierdie langdurige en moeisame stryd wat met talle struikelblokke en mislukkings gepaard gaan, dikwels juis op dié stadium dat oorwinning byna 'n uitgemaakte saak is, speel hom agter die skerms af en die publiek word daarvan bewus slegs wanneer die uiteindelike triomf aangekondig word. Die stryd teen die gevreesde polio bevestig hierdie stelling by uitnemendheid.

$\mathrm{Na}$ die ontdekking dat polio deur ' $\mathrm{n}$ virus veroorsaak word en lg. suksesvol geïsoleer is, moes vasgestel word hoe dit versprei en langs watter weë die menslike liggaam besmet word. Die siekte versprei geweldig vinnig en hierdie inligting was noodsaaklik om die verspreiding so doeltreffend moontlik te kon bekamp onderwyl die dringendste vraagstuk van almal $\mathrm{nl}$. die soektog na middels vir die genesing en veral vir die voorkoming daarvan, onopgelos gebly het. Geen welslae met pogings tot immunisasie kon verwag word sonder 'n kennis van die eienskappe van die virus nie en vir bestudering hiervan moes die virus op groot skaal in die laboratorium gekweek word. Ook moes diere gevind word waarin die virus nie alleen aard nie maar waarin, na eksperimentele besmetting, kliniese en patologiese simptome, soortgelyk an dié by die mens, ontstaan. Vir die kweek van virusse is lewende weefselkulture noodsaaklik. Onder andere is ontwikkelende kuikenembrio's, selle van mensen aaptestes en aapniere gebruik waarvan lg. tans algemeen gebruik word. Dit is ook vasgestel dat die siekte by die aap soortgelyk is aan dié by die mens.

Die soektog na suksesvolle immunisasiemetodes het nog dringender en ingewikkelder geword toe in 1949 ontdek is dat daar drie duidelik verskillende immunologiese tipes van die virus bestaan nl. Brunhilde (Tipe 1), Lansing (Tipe 2) en Leon (Tipe 3). Aldrie tipes veroorsaak polio onafhanklik van mekaar. Tipe 1 is vir $80 \%$ van die gevalle van die siekte verantwoordelik maar polio a.g.v. enige een van die drie verleen nie immuniteit teen die oorblywende twee nie. 'n Persoon wat van polio herstel het nadat hy met slegs een van die drie tipes besmet was is derhalwe nog altyd blootgestel aan 'n tweede en selfs 'n derde aanval wat kan volg op besmetting met een van die ander. Dit is dus nodig dat die ontwikkeling van immuniteit teen aldrie gestimuleer word. Die implikasie strek egter nog verder. Terwyl drie verskillende tipes reeds bekend is kan die moontlikheid dat nog nuwes deur mutasies gevorm kan word nie uit die oog verloor word nie. Doeltreffende immunisasiemetodes moet derhalwe gevind word om die bekende tipes onskadelik te stel voordat nuwe tipes gevorm kan word om die bestaande vaksiene nuttc- 
loos te maak vir voorkoming van die siekte.

Die gebruik van ten volle virulente virusse vir aktiewe kunsmatige immunisasie is te gevaarlik. Daarteenoor stimuleer dic aanwending van dooie virusse nie die ontwikkeling van sterk immuniteit nie. 'n Ander uitweg wat geen gevaar vir die mens inhou nie en tog sterk immuniteit teweegbring moes dus gevind word. Die antwoord is in 1954 aangekondig nadat dit met sukses op ape op die proef gestel is. Om egter bo alle twyfel vas te stel dat dit veilig was, is verdere toetse uitgevoer totdat dit in Suid-Afrika in 1956 vir die eerste maal gebruik is hoewel Salk dit in Amerika reéds in 1953 op kinders op die proef gestel het. Aldrie tipes van die virus is in die vaksiene aanwesig. Hulle is nog lewend maar is geinaktiveer deur behandeling met 'n swak konsentrasie van formalien. Dit dood nie die virusse nie maar vernietig alleen hul vermoë tot vermenigvuldiging en om die weefselselle aan to val en te vernietig. As reaksie op die inspuiting van die geinaktiveerde virusse word spesifieke teenliggame in die bloed gevorm wat die virusse vernietig sodra dit in die bloedstroom beland en wat ongeveer $80 \%$ van die geïmmuniseerde persone teen die siekte sal beskerm.

Hiermee is die probleem egter nie opgelos nie. Die roete wa.arlangs besmetting met dié virus opgedoen word is die spysverteringskanaal. Die siekte word voorafgegaan deur intestinale besmetting waarteen die teenliggame in die bloed die persoon nie beskerm nie. Hoewel die geïmmuniseerde persoon dus vir die siekte onvatbaar is kan hy nogtans intestinale besmeting opdoen as gevolg waarvan hy 'n draer daarvan word en 'n gevaar vir sy medemens is. Die kwaadaardige virusse vermenigvuldig in sy ingewande en word saam met die faeces vrygestel sodat hulle opnuut ander persone kan besmet. Pogings moet dus ook aangewend word om intestinale besmetting te voorkom deur die persoon op so ' $n$ wyse te immuniseer dat ook sy spysverteringskanaal onvatbaar vir besmetting is. Die klaarblyklike antwoord hierop is om die vaksiene toe te dien langs dieselfde weg as waardeur besmetting plaasvind $\mathrm{nl}$. deur die mond. Ondervinding met pokke en geelkoors toon dat immunisasie baie meer effektief is indien van lewende verswakte virusse gebruik gemaak word, d.w.s. virusse wat so behandel is dat hulle ten volle lewenskragtig bly maar hul kwaadaardigheid of vermoë om siekte te veroorsaak verloor. Die immuniteit wat hierdeur verwerf word is vergelykbaar met dié wat natuurlikerwys verwerf word. Dieselfde beginsel word toegepas by die bereiding van die poliovaksiene vir toediening deur die mond. Die virusse word verswak sodat hulle hul kwaaraardigheid en neurotropiese aktiwiteit, d.w.s. hul affiniteit vir en vermoë tot beskadiging van senuweeweefsel, verloor.

Die vaksiene wat die lewende verswakte virusse in pilvorm bevat is reeds berei en in verskillende lande op die proef gestel. Dit sal na verwagting nie alleen die vorming van teenliggame in die bloed stimuleer nie maak ook die ingewande vir besmetting onvatbaar 
maak. Aangesien dit 'n lewende virus is, sal dit in die spysverteringskanaal vermenigvuldig en saam met die faeces vrygestel word sodat nie-geïmmuniseerde persone met die verswakte virus besmet kan raak en natuurlike immuniteit sonder gevaar van siekte kan verwerf.

Die vordering wat reeds gemaak is beteken egter nie die einde van die probleem nie. Baie dele van die ingewikkelde legkaart ontbreek nog en kan alleen deur voortgesette navorsing aangevul word. Dieselfde geld ook t.o.v. baie ander siektes en reeds bekende maatreëls vir hulle voorkoming.

In Suid-Afrika skep die teenwoordigheid van die Bantoe besondere probleme t.o.v. openbare gesondheid en is dit nodig om hulle meer gesondheidsbewus te maak. Veel word reeds vir hulle gedoen maar baie meer behoort gedoen te word om sodoende ook die gesondheid van die blanke te beveilig. Die doeltreffendste wyse waarop dit kan geskied is deur hul eie mense in die geheimenisse van voorkomende gesondheidsdienste op te lei om hulle intensief te kan bedien.

Noodwendig kon hier slegs in breë trekke verwys word na die belangrikste aspekte van die besondere onderwerp wat ook die studietterrein vir studente in Higiëne aan die Potchefstroomse Universiteit is. Hier kan 'n besondere taak verrig word ter bevordering van die gesondheid van ons medemens. Ons kan en mag nie ons verantwoordelikheid ontduik deur onsself te probeer verontskuldig en soos Kain te vra, "Is ek my broer se wagter?" nie.

\section{VAN EEDEN.}




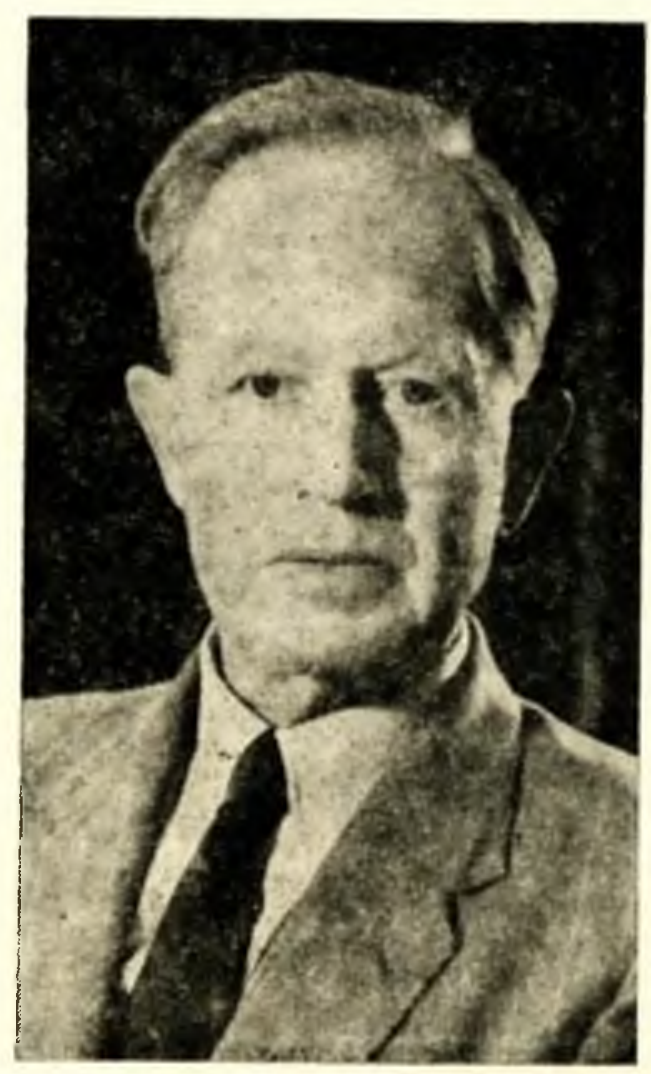

Prof. dr. D.J. du Plessis 